\title{
Gabungan Ekstrak Rimpang Temulawak, Daun Tanjung, dan Daun Belimbing Manis Berdasarkan Electrocardiogram Berpotensi Sebagai Antiaritmia pada Kucing
}

\author{
(A COMBINATION OF MIMUSOPS ELENGI L. AVERRHOA CARAMBOLA L. \\ AND CURCUMA XANTHORRIHIZA ROXB BASED ON ELECTROGRAM \\ ARE POTENTIALLY ANTIARRHYTHMIC IN CATS)
}

\author{
Min Rahminiwati ${ }^{1}$, Widia Safitri ${ }^{1}$, Deni Noviana ${ }^{2}$ \\ ${ }^{1}$ Bagian Farmakologi, Departement Anatomi, Fisiologi, dan Farmakologi, \\ ${ }^{2}$ Bagian Bedah dan Radiologi, Departement Klinik, Reproduksi, dan Patologi, \\ Fakultas Kedokteran Hewan, Institut Pertanian Bogor, \\ Jln Agathis, Kampus IPB, Dramaga, Bogor, \\ Jawa Barat, Indonesia 16680 \\ email: minrahminiwati@yahoo.com
}

\begin{abstract}
ABSTRAK
Ekstrak daun tanjung, daun belimbing dan rimpang temulawak dilaporkan mempunyai efek hipotensif. Salah satu mekanisme terjadinya penurunan tekanan darah adalah melalui perubahan kinerja jantung. Efek gabungan ekstrak daun tanjung, daun belimbing manis dan rimpang temulawak terhadap kinerja jantung telah diteliti menggunakan elektrokardiogram (EKG) pada 12 ekor kucing lokal dewasa berjenis kelamin jantan yang dikelompokkan ke dalam tiga kelompok perlakuan yaitu kucing yang diberi cairan pelarut sebagai kontrol negatif, gabungan ekstrak 21 mg dan $82 \mathrm{mg} / 2 \mathrm{~kg}$ bobot badan kucing secara per oral. Ekstrak diberikan tiga jam sebelum dilakukan pengamatan. Data yang diperoleh menunjukkan adanya penurunan Gelombang $\mathrm{P}$, QRS kompleks dan kecepatan degup jantung, serta peningkatan interval PR dan QT setelah pemberian gabungan ekstrak. Hal ini menunjukan bahwa gabungan ekstrak tersebut dapat melemahkan kontraksi atrium dan ventrikel, memperpanjang onset terjadinya kontraksi atrium menuju kontraksi ventrikel, memperpanjang onset kontraksi dan relaksasi ventrikel dan menimbulkan penurunan denyut jantung. Berdasarkan sifat perubahan yang terjadi pada EKG, ekstrak gabungan ketiga tanaman berpotensi sebagai antiaritmia jantung.
\end{abstract}

Kata-kata kunci: daun tanjung; daun belimbing; kunyit; aritmia jantung; EKG

\begin{abstract}
Mimusops elengi L. , Averrhoa carambola L. and Curcuma xanthorrihiza Roxb singly were reported to have hypothensif effect. Mechanism underlying decrease of blood pressure was suggested through modification of cardiac activity. The Effect of Mimusops elengi L., combined with Averrhoa carambola L. and Curcuma xanthorrihiza Roxb extract on cardiac activity were studied using ECG on 12 male cats that were grouped to be a control group administered aquadestilata, and treatment group administered extract of $21 \mathrm{mg}$ and $82 \mathrm{mg} / 2 \mathrm{~kg}$ bw orally respectively. The extracts were given $3 \mathrm{~h}$ prior to ECG. The results showed a decrease in $\mathrm{P}$ wave, QRS complex and the speed of the heart rate after administration of combination of extract. However QT and PR intervals were increased. This showed that the extract can weaken a contraction of the Atria and ventricles, prolonging the onset of the occurrence of atrial contraction towards ventricular contraction, extending the onset of contraction and relaxation of the ventricles and cause a decrease in heart rate. Based the cardiogram, It was concluded that their combination is valuable for treatment of aritmia.
\end{abstract}

Keywords: Mimusops elengi L.; Averrhoa carambola L.; Curcuma xanthorrihiza Roxb.; ECG 


\section{PENDAHULUAN}

Penyakit kardiovaskuler merupakan salah satu penyakit yang menjadi permasalahan cukup serius dewasa ini. World Health Organization (WHO 2012) mengemukan sekitar $31 \%$ kematian di seluruh dunia disebabkan oleh penyakit kardiovaskuler, di antaranya penyakit jantung. Di Indonesia, prevalensi penyakit jantung pada populasi yang berumur di atas 15 tahun adalah sebesar 9,2\%, dengan gejala terbanyak adalah aritmia dan angina pectoris (Delima et al., 2009).

Secara klinis penanggulangan kelainan jantung dengan menggunakan obat obatan konvensional seperti digitalis, procainamide dan encainid telah dilakukan. Namun demikian, pencarian bahan berkhasiat obat yang potensial untuk mencegah atau menanggulangi penyakit jantung tetap dilakukan. Hal ini sejalan dengan meningkatnya prevalensi penyakit kardiovaskuler akibat adanya perubahan gaya hidup,

Daun tanjung (Mimusops elengi L.), dan belimbing manis (Averrhoa carambola L.) serta Rimpang Temulawak (Curcuma xanthorrihiza) berpotensi sebagai obat untuk mengendalikan penyakitjantung. Dugaan ini berdasarkan pada efek farmakologi yang terdapat pada ketiga tanaman tersebut. Ekstrak daun tanjung dilaporkan mempunyai efek sebagai antioksidan, analgesik, antipiretik, diuretik dan antihipertensi (Kadan, ZOR Manjeshwar et al. 2011 Septian dan Widyaningsih 2014). Efek hipotensif dari ekstrak dapat diblok oleh inhibitor kalsium verapamil (Behbahanian et al., 1999). Hasil analisis fitokimia yang dilakukan Gami (2012) dan Roqaiya (2015) menunjukkan ekstrak aquades daun tanjung mengandung quercetin atau flavonoid, sterol, turunan gula dan tanin

Daun A. carambola atau belimbing manis, mengandung alkaloid, glikosida, fenol, tanin dan flavonoid (Poongodi dan Nazeema, 2016). Baik daun (Soncini et al. 2011), maupun buah belimbing (Wijaya et al., 2012) mempunyai efek menurunkan tekanan darah. Selain berkaitan dengan efek diuresis, efek hipotensif belimbing manis seperti dilaporkan oleh Vasconcelos et al. (2005) kemungkinan terjadi melalui mekanisme inhibisi terhadap denyut dan kekuatan kontraksi otot jantung akibat adanya inhibisi terhadap $\mathrm{Ca}^{++}$(Soncini et al., 2011).

Rimpang temulawak umumnya digunakan dalam industri makanan lokal dan memiliki nilai-nilai terapi. Salah satu ciri khas dari rimpang temulawak yang membedakannya dari famili yang lain adalah hemaglutinasi (Rukayadi 2006). Menurut Srivita (2012), komponen utama dalam rimpang temulawak terbagi atas tiga fraksi yaitu fraksi pati $48,00-$ $59,64 \%$, kurkuminoid $1,6-2,2 \%$, dan minyak atsiri 1,48-1,63\%. Kandungan kurkuminoid dalam rimpang temulawak kering berkisar $3,16 \%$ yang terdiri atas kurkumin ( $58-71 \%$ ) dan desmetoksikurkumin (29-42\%) (Hatmi dan Febrianty, 2014), sedangkan metabolit sekunder yang terdapat pada ekstrak air rimpang temulawak adalah terpenoid, fenol, flavonoid dan saponin (Rohaimi et al., 2012). Ekstrak temulawak dapat mengembalikan kadar serotonin dan dopamin pada hewan yang mengalami penurunan norepinefrin, serotonin dan dopamin akibat stress (Kulkarni dan Dhir, 2010), selain mempunyai efek farmakologis sebagai antiinflamasi, antihipertensi dan antihiperlipidemia.

Hasil analisis fitokimia baik daun tanjung, belimbing manis maupun rimpang temulawak, mengandung flavonoid, fenol, saponin dan tanin. Senyawa flavonoid dan fenol dilaporkan oleh beberapa peneliti dapat menurunkan tekanan darah melalui mekanisme hambatan terhadap sistem saraf simpatis (simpatolitik) atau meningkatkan kerja parasimpatik (parasimpatomimetik), yaitu relaksasi otot atau melalui syaraf pusat. Kerja simpatolitik dalam menurunkan tekanan darah dapat melalui berbagai mekanisme di antaranya adalah menurunkan curah jantung melalui penghambatan reseptor $\beta 1$, mendilatasi pembuluh darah melalui penghambatan reseptor $\alpha 1$ atau melalui penghambatan pelepasan neurotransmitter androgenik.

Aktivitas jantung merupakan hasil dari perubahan muatan listrik jantung sebagai hasil dari depolarisasi dan repolarisasi sel sel otot jantung. Aktivitas listrik pada otot jantung yang mendasari kerja jantung secara faal dipengaruhi oleh sistem saraf otonom simpatis dan parasimpatis. Oleh karena kerja sistem saraf ini juga dapat diinterferensi oleh ketiga ekstrak tersebut, gabungan ekstrak ketiga tanaman itu diduga dapat memengaruhi kerja listrik dan kecepatan denyut jantung.

Gelombang depolarisasi yang merupakan aliran listrik, dapat dideteksi dengan elektrodaelektroda yang ditempatkan di permukaan tubuh dan adanya perubahan pada gambaran listrik jantung dapat dilihat dengan Elektro Kardiograf (EKG). Penelitian ini dilakukan bertujuan untuk mengetahui efek gabungan 
ekstrak daun tanjung (Mimusops elengi L.), daun belimbing manis (Averrhoa carambola L.) dan rimpang temulawak (Curcuma xanthorrihiza Roxb.) terhadap gambaran EKG jantung kucing sebagai model. Kucing merupakan hewan coba yang sering digunakan dalam penelitian dan lebih efisien dalam pemeriksaan dengan menggunakan EKG dibandingkan hewan coba lainnya seperti tikus, kelinci dan mencit. Selain itu menurut Buchanan (1999) dan Payne et al. (2015), 10\% dari populasi kucing di seluruh dunia menderita penyakitjantung .

\section{METODE PENELITIAN}

\section{Penyiapan Bahan}

Daun belimbing manis (Averrhoa carambola L.), daun tanjung (Mimusops elengi $L$. (tanjung), dan rimpang Curcuma xanthorrhiza Roxb. (temulawak) diperoleh dari sekitar Dramaga, Bogor, Jawa Barat.

Daun tanjung, daun belimbing dan rimpang temulawak disortasi untuk memisahkan ketiga tanaman tersebut dari pencemar, kemudian dicuci dengan air mengalir dan ditiriskan. Rimpang temulawak dirajang, selanjutnya rajangan rimpang temulawak, daun tanjung dan daun belimbing dikeringkan di bawah sinar matahari. Setelah kering, ketiga simplisia disortasi kering dan dibuat menjadi serbuk dengan derajat halus 40 mesh.

Ekstraksi Bahan. Sebanyak $50 \mathrm{~g}$ serbuk simplisia daun tanjung, daun belimbing dan temulawak masing masing setelah ditambahkan $600 \mathrm{~mL}$ aquadestilata, dipanaskan di atas penangas air bersuhu $90^{\circ} \mathrm{C}$ selama tiga jam terhitung mulai air bersuhu $90^{\circ} \mathrm{C}$ sambil sesekali diaduk. Selanjutnya cairan ekstrak disaring selagi panas menggunakan kain flannel. Filtrat yang diperoleh dari proses penyaringan tersebut, dienaptuangkan dan dipekatkan dengan cara penguapan menggunakan evaporator suhu $70^{\circ} \mathrm{C}$. Untuk mempermudah pemberian, ketiga ekstrak kering digabung dan dimasukkan ke dalam kapsul no 1. Gabungan ekstrak tersebut terdiri dari 11,78 g ekstrak daun tanjung, 3,74 g daun belimbing dan 4,4 ekstrak temulawak. Sebagian dari gabungan ekstrak tersebut digunakan untuk analisis fitokimia yang meliputi identifikasi alkaloid, flavonoid, saponin, triterpenoid, steroid dan tannin. Identifikasi alkaloid dilakukan mengikuti metoda yang dipaparkan DEPKES (1995), sedangkan identifikasi flavonoid, saponin, triterpenoid, steroid, dan tannin mengacu pada metoda yang dipaparkan Hanani (2015).

\section{Uji Fitokimia}

Identifikasi Alkaloid. Sebanyak 500 mg gabungan ekstraks setelah ditambah $1 \mathrm{ml}$ $\mathrm{HCl} 2 \mathrm{~N}$ dan $9 \mathrm{~mL}$ air suling, dipanaskan selama dua menit kemudian didinginkan dan disaring. Filtrat yang diperoleh dimasukkan ke dalam tiga tabung yang berbeda diikuti dengan penambahan pereaksi Dragendorff, Bouchardat atau Mayer. Hasil uji fitokimia dinyatakan positif bila masing terbentuk endapan merah atau jingga setelah penambahan pereaksi Dragendorff dan pereaksi Bouchardat dan endapan putih pada penambahan pereaksi Mayer ( Depkes 1995).

Identifikasi Flavonoid. Sebanyak $1 \mathrm{~mL}$ gabungan ekstrak dilarutkan dalam $3 \mathrm{~mL}$ metanol (larutan uji), kemudian diuapkan hingga kering. Dua sampai tiga tetes etanol ditambahkan dalam sediaan uji yang sudah dikeringkan. Hasil dinyatakan positif mengandung flavonoid bila setelah penambahan serbuk magnesium dan beberapa tetes asam klorida 5M terbentuk warna merah hingga merah tua.

Identifikasi Saponin. Sebanyak 0,5 g gabungan ekstrak dikocok dengan $10 \mathrm{~mL}$ air (jika perlu dipanaskan sebentar di atas penangas air). Reaksi positif ditunjukkan dengan adanya busa yang stabil dengan penambahan asam klorida.

Identifikasi Triterpenoid. Sebanyak 0,5 g gabungan ekstraks dimasukkan ke dalam tabung reaksi kemudian ditambahkan $2 \mathrm{~mL}$ etanol 70\% dan dihomogenkan. Selanjutnya ke dalam campuran tersebut berturut-turut ditambahkan $1 \mathrm{~mL}$ kloroform dan $1 \mathrm{~mL}$ asetat anhidrida kemudian dibiarkan sampai dingin. Warna kemerahan yang terbentuk setelah penambahan $\mathrm{H}_{2} \mathrm{SO}_{4}$ pada larutan yang sudah dingin, menunjukan adanya triterpenoid.

Identifikasi Steroid. Sebanyak 0,5 g gabungan ekstrak kering daun tanjung, belimbing dan ekstrak temulawak ditambah 2 $\mathrm{mL}$ etanol $70 \%$. dan dihomogenkan. Selanjutnya ke dalam campuran tersebut ditambahkan $2 \mathrm{~mL}$ kloroform dan $2 \mathrm{~mL} \mathrm{H}_{2} \mathrm{SO}_{4}$ pekat dengan cara diteteskan pelan-pelan dari sisi dinding tabung reaksi. Cincin warna merah yang terbentuk setelah penetesan $\mathrm{H}_{2} \mathrm{SO}_{4}$ menunjukkan adanya steroid. 
Identifikasi Tanin. Larutan tanin mengendap dengan penambahan logam berat atau gelatin (protein) $1 \%$ dalam natrium klorida $10 \%$.

\section{Prosedur Uji In Vivo}

Hew an percobaan yang digunakan dalam penelitian ini adalah kucing lokal berjenis kelamin jantan dengan bobot badan sekitar 2-3 $\mathrm{kg}$. Setelah diaklimatisasi selama dua minggu, kondisi kesehatan kucing diperiksa melalui pemeriksaan fisik dan pemeriksaan laboratorium terhadap adanya infestasi parasit cacing.

Kucing yang sehat, sebanyak 12 ekor, kemudian dikelompokkan menjadi tiga kelompok perlakuan yaitu kelompok 1 sebagai kontrol negatif diberi akuadestilata, kelompok 2 diberi gabungan ekstrak dosis $21 \mathrm{mg} / \mathrm{kg}$ bb dan kelompok 3 diberi gabungan ekstrak $82 \mathrm{mg} /$ $\mathrm{kg}$ bb per oral.

Sebelum perlakuan, kucing dipuasakan terlebih dahulu selama 24 jam. Rambut kucing dicukur pada daerah ulna atau siku di kedua kaki depan dan daerah patela di kedua kaki belakang. Bagian yang telah dicukur diolesi dengan transmission gel. Kucing diletakkan dengan posisi lateral recumbency. Sadapan yang bewarna merah dipasang pada kaki kanan depan (RA), sadapan bewarna kuning dipasang pada kucing kaki kiri depan (LA), sadapan bewarna hijau dipasang pada kaki belakang kiri (LL) dan sadapan bewarna hitam dipasang pada kaki kanan belakang (RL). Konduksi jantung direkam dengan menggunakan EKG dan hasilnya muncul pada kertas EKG. Kertas EKG merupakan segulungan kertas grafik kontinu yang panjang dengan garis-garis tebal dan tipis, vertikal dan horizontal. Garis tipis membatasi kotak-kotak kecil seluas $1 \mathrm{x} 1 \mathrm{~mm}$, garis tebal membatasi kotak-kotak besar seluas $5 \times 5 \mathrm{~mm}$. Sumbu horizontal mengukur waktu. Jarak satu kotak kecil adalah 0,04 detik. Jarak satu kotak besar adalah lima kali lebih besar atau 0,2 detik. Sumbu vertikal mengukur voltage. Jarak satu kotak kecil adalah sebesar $0,1 \mathrm{mV}$ dan satu kotak besar adalah sebesar 0,5 mV. Evaluasi dilakukan pada kertas EKG yang diawali dengan pengamatan terhadap ada atau tidaknya kompleks QRS dan gelombang T yang mengikuti gelombang $\mathrm{P}$ kemudian dilanjutkan pada pengukuran interval/durasi dan amplitudo setiap gelombang. Gambaran EKG kucing direkam pada waktu sebelum dan sesudah pemberian ekstrak
Semua data yang diperoleh dari hasil penelitian dianalisa dengan menggunakan sidik ragam satu arah. Data yang berbda secara nyata, dilakukan uji lanjut Tukey. Perbedaan dianggap signifikan secara statistikajika $p<0,05$ dalam semua kasus.

\section{HASIL DAN PEMBAHASAN}

Proses ekstraksi terhadap 500 g serbuk daun tanjung, daun belimbing dan temulawak, menghasilkan ekstrak kental masing-masing sebanyak $25 \mathrm{~g}, 40 \mathrm{~g}$, dan $60 \mathrm{~g}$, dengan perolehan rendemen masing masing ekstrak tersebut ialah sebanyak 5,8\% dan $12 \%$ (Tabel 1). Hasil uji fitokimia menunjukkan adanya alkaloid, saponin, tannin, fenol, flavonoid, dan triterpenoid pada gabungan ekstrak daun tanjung, daun belimbing, dan temulawak namun tidak terdeteksi adanya steroid (Tabel 2) .

Gambaran EKG kucing sebelum dan sesudah pemberian ekstrak disajikan pada Gambar 1 dan Tabel 2. Gambaran EKG yang normal untuk kucing disajikan pada Tabel 3 . Pada tabel tersebut secara umum gambaran EKG kucing sebelum perlakuan memenuhi kriteria kucing normal, seperti yang dilaporkan oleh Buchanan (2016).

Setelah perlakuan, gambaran EKG kucing menunjukkan adanya perubahan pada gelombang $\mathrm{P}$, gelombang QRS, interval PR dan laju degup jantung/heart rate kucing. Durasi Gelombang $\mathrm{P}$ yang awalnya $0,04 \pm 0,00$ detik (sebelum) menjadi 0,03 $\pm 0,00$ detik sesudah diberi ekstrak gabungan kedua dosis tersebut atau terjadi penurunan durasi gelombang sebesar 25\%, sedangkan QRS pada kelompok kucing yang diberi dosis $82 \mathrm{mg} / 2 \mathrm{~kg} \mathrm{bb}$, gelombang $\mathrm{P}$ berubah dari $0,07 \pm 0,00$ detik (sebelum) menjadi 0,05 $\pm 0,01$ detik (sesudah) atau terjadi penurunan durasi sebesar 28,57 $\%$. Pada kelompok yang diberi dosis $82 \mathrm{mg} / 2 \mathrm{~kg}$ bb. sebaliknya menunjukkan adanya peningkatan durasi interval PR sebesar 25\% yaitu dari 0,08 $\pm 0,01$ detik (sebelum) menjadi $0,10 \pm 0,00$ detik (sesudah). Selain durasi interval PR, durasi QT juga menunjukkan adanya perubahan pada kucing yang diberi dosis $21 \mathrm{mg} / 2 \mathrm{~kg}$ bb yaitu dari $0,11 \pm 0,01 \mathrm{detik}$ (sebelum) menjadi 0,15 $\pm 0,01$ detik (sesudah) atau terjadi peningkatan sebesar $36,36 \%$ dan $0,17 \pm 0,01$ detik (sebelum) menjadi $0,20 \pm 0,01$ detik (sesudah) atau terjadi peningkatan sebesar $17,65 \%$ pada dosis $82 \mathrm{mg} / 2 \mathrm{~kg}$ bb. Perubahan gambaran EKG lainnya yang teridentifikasi 
Tabel 1. Perhitungan rendemen ekstrak dauntanjung, daun belimbing dan rimpang temulawak yang diperoleh

\begin{tabular}{lccc}
\hline & Daun Tanjung & Daun belimbing & Rimpang temulawak \\
\hline Berat serbuk $(\mathrm{g})[\mathrm{a}]$ & 500 & 500 & 500 \\
Jumlah ekstrak $(\mathrm{g})[\mathrm{b}]$ & 25 & 40 & 60 \\
Kadar rendemen $(\%)=\mathrm{b} / \mathrm{a} \times \mathrm{x}$ 100\% & 5 & 8 & 12 \\
\hline
\end{tabular}

Tabel 2. Hasil uji fitokimia terhadap gabungan ekstrak daun tanjung, daun belimbing manis dan rimpang temulawak dengan metode kualitatif

\begin{tabular}{lc}
\hline Jenis pemeriksaan & Hasil pengujian \\
\hline Alkaloid & + \\
Saponin & + \\
Tanin & + \\
Fenolik & + \\
Flavonoid & + \\
Triterpenoid & + \\
Steroid & - \\
\hline
\end{tabular}

Keterangan : (+) ada, (-) tidak ada
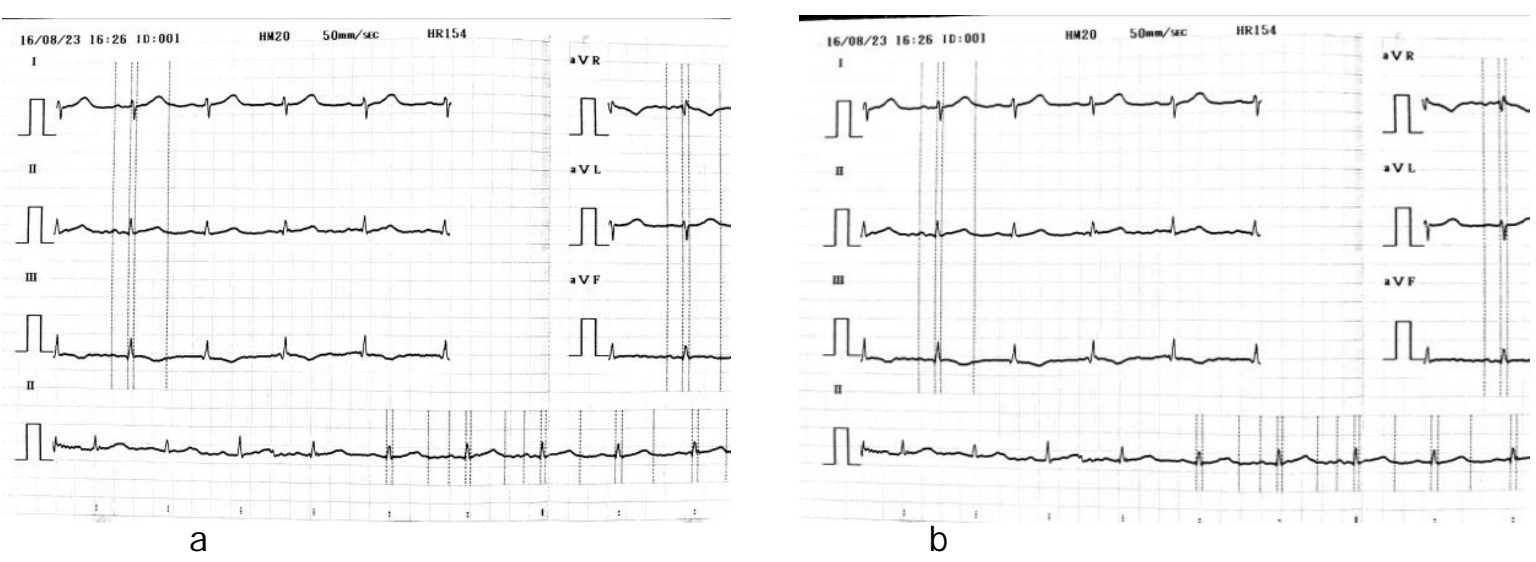

Gambar 1. Gambaran elektrokardiogram (EKG) sebelum (a) dan sesudah (b) pemberiangabungan ekstrakpada Sadapan I antara kaki depan bagian kanan dengan kaki depan bagian kiri, sadapan II antara kaki depan bagian kanan dengan kaki belakang bagian kiri, Sadapan III antara kaki depan bagian kiri dengan kaki belakang bagian kiri

Tabel 3. Ciri-ciri elektrokardiogram normal pada kucing (Buchanan 2016)

\begin{tabular}{llll}
\hline & Parameter & Voltase $(\mathrm{mV})$ & Durasi (detik) \\
\hline Gelombang & $\mathrm{P}$ & $<0,2$ & $<0,04$ \\
& $\mathrm{QRS}$ & $<0,9$ & $<0,04$ \\
Interval & $\mathrm{T}$ & Defleksi positif, negatif atau bifasik \\
& $\mathrm{PR}$ & $0,05-0,09$ & \\
& $\mathrm{QT}$ & $0,12-0,18$ &. \\
Heart Rate & $\mathrm{ST}$ & Tidak depresi atau elevasi & \\
\hline
\end{tabular}


Tabel 4. Perubahan gambaran elektrokardiogram (EKG) kucing sebelum dan sesudah diberi ekstrak.

\begin{tabular}{|c|c|c|c|c|c|c|}
\hline & \multirow{2}{*}{\multicolumn{2}{|c|}{ Kontrol }} & \multicolumn{4}{|c|}{ Perlakuan } \\
\hline & & & \multicolumn{2}{|c|}{ Dosis $21 \mathrm{mg} / 2 \mathrm{~kg} \mathrm{BB}$} & \multicolumn{2}{|c|}{ Dosis $82 \mathrm{mg} / 2 \mathrm{~kg} \mathrm{BB}$} \\
\hline & Sebelum & Sesudah & Sebelum & Sesudah & Sebelum & Sesudah \\
\hline $\mathrm{P}(\mathrm{s})$ & $0,04 \pm 0,00^{b}$ & $0,04 \pm 0,06^{b}$ & $0,04 \pm 0,06^{b}$ & $0,02 \pm 0,06^{\mathrm{a}}$ & $0,03 \pm 0,01^{\mathrm{ab}}$ & $0,02 \pm 0,00^{\mathrm{a}}$ \\
\hline $\mathrm{P}(\mathrm{mV})$ & $0,17 \pm 0,06$ & $0,17 \pm 0,06$ & $0,13 \pm 0,06$ & $0,13 \pm 0,06$ & $0,17 \pm 0,06$ & $0,13 \pm 0,06$ \\
\hline QRS(s) & $0,04 \pm 0,01^{\mathrm{ab}}$ & $0,04 \pm 0,02^{\mathrm{a}}$ & $0,53 \pm 0,12^{\mathrm{ab}}$ & $0,04 \pm 0,01^{\mathrm{a}}$ & $0,07 \pm 0,10^{\mathrm{b}}$ & $0,05 \pm 0,02^{\mathrm{ab}}$ \\
\hline $\mathrm{QRS}(\mathrm{mV})$ & $0,60 \pm 0,10^{\mathrm{ab}}$ & $0,68 \pm 0,06^{b}$ & $0,57 \pm 0,12^{\mathrm{ab}}$ & $0,50 \pm 0,00^{\mathrm{a}}$ & $0.57 \pm 0,06^{\mathrm{ab}}$ & $0,57 \pm 0,08^{\mathrm{ab}}$ \\
\hline $\mathrm{T}(\mathrm{s})$ & $0,04 \pm 0,00^{\mathrm{a}}$ & $0,06 \pm 0,01^{b}$ & $0,05 \pm 0,01^{\mathrm{a}}$ & $0,05 \pm 0,02^{\mathrm{ab}}$ & $0,07 \pm 0,01^{b}$ & $0,07 \pm 0,01^{\mathrm{b}}$ \\
\hline $\mathrm{T}(\mathrm{mV})$ & $0,17 \pm 0,12$ & $0,28 \pm 0,08$ & $0,23 \pm 0,29$ & $0,17 \pm 0,06$ & $0,17 \pm 0,06$ & $0,18 \pm 0,10$ \\
\hline PR & $0,06 \pm 0,00^{\mathrm{a}}$ & $0,07 \pm 0,01^{\mathrm{ab}}$ & $0,07 \pm 0,00^{\mathrm{ab}}$ & $0,10 \pm 0,01^{\mathrm{c}}$ & $0,07 \pm 0,01^{\mathrm{b}}$ & $0,09 \pm 0,01^{\mathrm{c}}$ \\
\hline QT & $0,16 \pm 0,01^{b}$ & $0,18 \pm 0,01^{\mathrm{c}}$ & $0,12 \pm 0,01^{\mathrm{a}}$ & $0,16 \pm 0,02^{b}$ & $0,17 \pm 0,01^{\mathrm{ab}}$ & $0,19 \pm 0,01^{\mathrm{c}}$ \\
\hline ST & $0,17 \pm 0,02^{\mathrm{a}}$ & $0,11 \pm 0,02^{\mathrm{a}}$ & $0,11 \pm 0,01^{\mathrm{a}}$ & $0,16 \pm 0,01^{\mathrm{b}}$ & $0,14 \pm 0,01^{\mathrm{b}}$ & $0,16 \pm 0,15^{b}$ \\
\hline HR & $1915 \pm 12,01^{\mathrm{c}}$ & $1616 \pm 10,21^{\mathrm{abc}}$ & $1756 \pm 22,37^{\mathrm{bc}}$ & $1533 \pm 30,55^{\mathrm{ab}}$ & $1813 \pm 6,03^{\mathrm{bc}}$ & $1343 \pm 9,81^{\mathrm{a}}$ \\
\hline
\end{tabular}

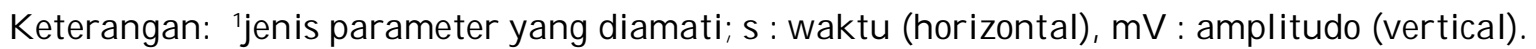
Superskrip yang berbeda pada baris yang sama menunjukkan adanya perbedaan yang signifikan pada $\mathrm{P}<0,05$

pada kucing selama perlakukan adalah heart rate. Heart rate kucing yang diberi $82 \mathrm{mg} / 2 \mathrm{~kg}$ bb, berubah dari $181,25 \pm 4,92 \mathrm{kali} /$ menit (sebelum) menjadi $143,50 \pm 20,00 \mathrm{kali} /$ menit atau terjadi penurunan sebesar $20,83 \%$.

Analisis statistika menggunakan sidik ragam satu arah (one-way analysis of variance) menunjukkan adanya pengaruh yang signifikan dari perlakuan dan hasil uji lanjut Tukey menunjukkan adanya perbedaan yang signifikan antar perlakuan $(\mathrm{P}<0,05)$.

Pada hasil rekaman EKG terdeteksi adanya gambaran durasi dan amplitudo dari gelombang $\mathrm{P}$, komplek QRS, dan gelombang T. Gelombang $\mathrm{P}$ dihasilkan oleh depolarisasi atrium jantung, gelombang T merupakan repolarisasi ventrikel jantung, kompleks QRS merupakan bentuk depolarisasi ventrikel jantung. Interval PR merupakan depolarisasi dari hantaran atrium jantung melalui simpul AV, interval QT merupakan depolarisasi ventrikel dan repolarisasi ventrikel jantung, interval ST merupakan repolarisasi ventrikel jantung dan heart rate adalah jumlah degup jantung per menit (Muttaqin 2009). Di antara ketiga gelombang tersebut,yang mengalami perubahan durasi sebelum dan sesudah pemberian ekstrak hanya terdapat pada durasi gelombang $\mathrm{P}$ kelompok dosis $21 \mathrm{mg} / 2 \mathrm{~kg}$ BB. Durasi gelombang $\mathrm{P}$ pada kelompok ini mengalami penurunan sebesar $50 \%$. Hal ini menunjukkan adanya peningkatan waktu kontraksi atrium.
Menurut Atsamo et al. (2013) asetilkolin yang dikeluarkan akibat peningkatan aktivitas parasimpatis menyebabkan terjadinya peningkatan permeabilitas nodus SA terhadap $\mathrm{K}^{+}$dengan memperlambat penutupan saluran $\mathrm{K}^{+}$. Peningkatan permeabilitas $\mathrm{K}^{+}$menyebabkan hiperpolarisasi membran nodus SA karena lebih banyak ion kalium yang keluar, akibatnya adalah kontraksi atrium menjadi lemah. Namun, berdasarkan efek ekstrak terhadap durasi dan amplitudo komplek QRS yang tidak mengalami perubahan yang bermaknsa, gabungan ekstrak daun tanjung, daun belimbing manis, dan rimpang temulawak tidak memengaruhi waktu ventrikel jantung untuk berkontraksi.

Hal yang menarik adalah durasi dan amplitudo gelombang T. Pada kelompok perlakuan antara sebelum dan sesudah pemberian gabungan ekstrak daun tanjung daun belimbing dan temulawak tidak menunjukkan adanya perubahan yang signifikan, namun pada kelompok kontrol terjadi peningkatan durasi dan amplitudo gelombang $\mathrm{T}$ sebesar $50 \%$ dalam rentang waktu tiga jam. Hal ini dapat terjadi karena terdapat dua ekor kucing pada kelompok kontrol memiliki nilai gelombang $\mathrm{T}$ yang cukup tinggi pada saat tiga jam setelah perlakuan. Peningkatan durasi gelombang T tersebut menunjukan terjadinya peningkatan waktu relaksasi pada ventrikel jantung. 
Selain amplitudo dan durasi gelombang $\mathrm{P}$, komplek QRS dan T, perubahan gambaran EKG juga teramati pada jarak atau rentang waktu yang dibutuhkan untuk menuju gelombang berikutnya yaitu interval, yang terdiri dari interval PR, QT dan ST. Pada interval PR terjadi peningkatan durasi interval $\mathrm{PR}$ pada kelompok dosis $21 \mathrm{mg} / 2 \mathrm{~kg}$ BB sebesar $42,86 \%$ dan kelompok dosis $82 \mathrm{mg} / 2 \mathrm{~kg}$ BB sebesar $28,57 \%$., Peningkatan interval PR pada kelompok dosis $21 \mathrm{mg} / 2 \mathrm{~kg}$ BB dan kelompok dosis $82 \mathrm{mg} / 2 \mathrm{~kg}$ BB lebih tinggi jika dibandingkan dengan kontrol. Peningkatan nilai interval PR menunjukan bahwa waktu hantaran listrik pada atrium jantung melalui simpuls AV menjadi lebih lama. Menurut Septian dan Widyaningsih (2014) senyawa fenol berperan penting dalam proses penurunan tekanan darah melalui mekanisme kerja simpatolitik. Senyawa ini bekerja menuju pusat jaringan yaitu sebagai $\alpha 1$ blocker. Interaksi antara senyawa aktif dengan reseptor $\alpha 1$ menyebabkan terjadinya vasodilatasi sehingga darah lebih mudah mengalir ke jantung. Darah dari pembuluh darah yang dialirkan ke jantung menjadi lebih lancar dan waktu pengisian atrium jantung menjadi lebih lama. Nurdiana (2008) juga menyatakan bahwa pengendalian kontraktilitas pembuluh darah didominasi oleh sistem saraf simpatis yang bekerja melalui pelepasan neurotransmiter norepinefrin di ujung saraf dan berikatan dengan reseptor $\alpha 1$-adrenergik pada otot polos pembuluh darah.

Peningkatan interval QT antara sebelum dan sesudah pemberian gabungan ekstrak daun tanjung daun belimbing dan temulawak juga terjadi pada kedua dosis. Kelompok perlakuan dengan dosis $21 \mathrm{mg} / 2 \mathrm{~kg}$ BB dan kelompok dosis $82 \mathrm{mg} / 2 \mathrm{~kg}$ BB masing masing mengalami peningkatan nilai interval QT berturut-turut sebesar $33,33 \%$ dan $11,76 \%$. Peningkatran interval QT pada kedua kelompok perlakuan lebih tinggi dari peningkatan interval QT pada kelompok kontrol yang mengalami perubahan sebesar $12,5 \%$. Jika dibandingkan dengan kontrol, kelompok dosis $21 \mathrm{mg} / 2 \mathrm{~kg}$ BB dan kelompok dosis $82 \mathrm{mg} / 2 \mathrm{~kg}$ BB mengalami peningkatan sebesar $11,11 \%$. Peningkatn nilai interval QT, menunjukan bahwa waktu dari kontraksi ventrikel jantung menuju relaksasi ventrikel jantung menjadi lebih lama.

Interval ST juga mengalami peningkatan nilai antara sebelum dan sesudah pemberian gabungan ekstrak daun tanjung daun belimbing dan temulawak pada kelompok dosis $21 \mathrm{mg} / 2$ kg BB yaitu sebesar $45,45 \%$. Sekitar $45,45 \%$ lebih tinggi dibandingkan kontrol. Hal ini menunjukan bahwa waktu untuk melakukan relaksasi ventrikel jantung lebih lama. Darah yang dialirkan dari atrium jantung menuju ventrikel jantung atau waktu pengisian darah pada ruang ventrikel jantung menjadi lebih lama. Menurut Septian dan Widyaningsih (2014) senyawa fenol juga dapat memengaruhi fungsi reseptor $\alpha 1$ yang secara dominan terdapat pada ventrikel jantung. Jika fungsi reseptor $\alpha 1$ dihambat maka kontraksi ventrikel jantung akan menjadi lebih lemah, sedangkan stimulasi reseptor $\alpha 1$ dapat menaikkan degup jantung dan kontraksi otot jantung sehingga otot-otot jantung dapat memompa darah dengan mudah karena menurunkan kontraktilitas jantung

Denyut jantung antara sebelum dan sesudah pemberian ekstrak daun tanjung daun belimbing dan temulawak berdasarkan data yang terdapat pada Tabel 4 , ternyata mengalami perubahan nilai sebesar $12,70 \%$ pada kelompok dosis $21 \mathrm{mg} / 2 \mathrm{~kg}$ BB dan sebesar 25,92\%. kelompok dosis $82 \mathrm{mg} / 2 \mathrm{~kg} \mathrm{BB}$. Menurut Theofilogiannakos (2013), reseptor â1-adrenergik memiliki peran penting pada kardiovaskuler dan neurohormonal homeostasis. Degup jantung, tekanan arteri, kontraktilitas myokardium, metabolisme glukosa dan fungsi penting lainnya secara langsung berhubungan dengan fungsi dari reseptor $\alpha 1$-adrenergik yang dirangsang oleh sekresi katekolamin. Penghambatan reseptor $\alpha 1$-adrenergik ini menyebabkan kontraksi ventrikel jantung menjadi lemah dan berpengaruh terhadap penurunan denyutjantung. Selain itu, interaksi antara reseptor alfa pada pembuluh darah dengan zat yang terkandung dalam gabungan ekstrak menyebabkan vasodilatasi pada pembuluh darah, sehingga darah mengalir lancar dan jantung melemah dan bekerja lebih rileks. Jika dibandingkan dengan kontrol, pada kelompok dosis $21 \mathrm{mg} / 2 \mathrm{~kg}$ terjadi penurunan sebesar 5,14\%, sedangkan dengan kelompok dosis $82 \mathrm{mg} / 2 \mathrm{~kg}$ terjadi penurunan sebesar $16,89 \%$.

Berdasarkan hasil evaluasi yang dilakukan terhadap EKG pada jantung kucing yang diberi gabungan ekstrak daun tanjung daun belimbing dan temulawak secara oral, terdapat penurunan pada gelombang $\mathrm{P}, \mathrm{QRS}$ dan heart rate, sedangkan gelombang $\mathrm{T}$ tidak ditemukan 
adanya perubahan. Selain itu, juga terjadi peningkatan durasi interval PR dan QT.

Gelombang $P$ dan komplek QRS menggambarkan adanya proses depolarisasi atrium dan ventrikel jantung. Penurunan waktu depolarisasi atrium dan ventrikel jantung tersebut menunjukan bahwa proses kontraksi atrium dan ventrikel jantung menjadi lebih cepat. Namun, dengan adanya peningkatan pada interval PR mengindikasikan bahwa proses depolarisasi atrium jantung menjadi lebih cepat dan waktu menuju depolarisasi ventrikel jantung lebih lama atau impuls dari AV node yang berasal dari SA node menjadi sedikit terhambat menuju Bundle his.

Perubahan yang terjadi pada interval QT yang tidak disertai dengan perubahan pada interval ST, berarti bahwa perubahan tersebut hanya terjadi pada durasi QRS komplek. Kondisi seperti ini dapat ditemukan pada waktu terjadi peningkatan waktu depolarisasi tanpa disertai dengan adanya perubahan waktu menuju repolarisasi ventrikel jantung. Selain itu, gabungan ekstrak daun tanjung daun belimbing dan temulawak juga menyebabkan penurunan heart rate. Hal ini menandakan terjadinya sinus bradichardi karena ekstrak gabungan tersebut menurunkan efek SA node. Depresi konduksi listrik atrio-ventriculer adalah efek yang sangat bermanfaat untuk meniadakan fibrilasi yang menyebabkan ventrikel jantung berkontraksi lebih cepat.

\section{SIMPULAN}

Hasil penelitian menunjukan bahwa ekstrak gabungan daun tanjung (M. elengi $L$.), daun belimbing manis (A. carambola L.) dan rimpang temulawak (C. xanthorrihiza Roxb., memiliki zat yang dapat memengaruhi sifat listrik jantung yaitu menurunkan durasi gelombang P dan QRS, meningkatkan interval PR dan QT, dan menurunkan heart rate.

\section{SARAN}

Efektivitas ramuan ekstrak daun tanjung, daun belimbing manis, dan rimpang temulawak sebagai antiaritmia perlu diteliti lebih lanjut pada anjing atau kucing penderita aritmia jantung.

\section{UCAPAN TERIMA KASIH}

Ucapan terima kasih dan penghargaan kami sampaikan kepada Direktur Rumah Sakit
Hewan, Institut Pertanian Bogor atas fasilitas dan bantuannya dalam pelaksanaan penelitian ini

\section{DAFTAR PUSTAKA}

Atsamo AD, Nene-bi SA, Kouakou KL, Fofie KC, Nyadjeu P, Watcho P, Datte JY, Kamanyi A, Nguelefack TB. 2013. Cardiovascular and antioxidant effect of the methanol extract from the stem bark of Erythrima senegalensis DC (Fabaceae). J Phys Pharm Adv 3(4): $110-120$

Buchanan J. 2016. Small Animal Cardiology. http://research.vet.upenn.edu/ smallanimalcardiology/Home/tabid/4911/ Default.aspx.diunduh pada tanggal 17 September 2016

Buchanan JW. 1999. Prevalence of cardiovascular disorders. Dalam: Textbook of canine and feline cardiology. Fox PR, Sisson DD, Moise NS, (Editors). $2^{\text {nd }}$ Ed. Philadelphia: WB Saunders. Hlm. 457 - 470.

Behbahanian DS, Malik A, Jahan N. 1999. Hypotensive effect of the methanolic extract of Mimusops elengi in normotensive rats. Phytomedicine 6(5): $373-378$

Delima L, Mihardja H, Siswoyo. 2009. Bul Penelit Kesehat (37)3: 142- 159

Depkes RI. 1995. Materia Medika Indonesia, Jilid VI. Jakarta: Direktorat Jendral Pengawasan Obat dan Makanan. 139-142.

Gami B, Smita P, Minoo P. 2012. Ethnobotanical, phytochemical and pharmacological review of Mimusops elengi Linn. Asian Pac J Trop Biomed 2(9): 743-748.

Hanani E. 2015. Analisis Fitokimia. Jakarta: Penerbit Buku Kedokteran EGC. Hlm. 7990

Hatmi RU, Febriyanti. 2014. Kandungan Kurkumin Rimpang Temulawak pada Tiga Tingkat Umur Panen dan Sistem Pemupukan Berbeda. Prosiding Seminar Nasional Pertanian Organik. Bogor, 1819 Juni 2014. Ballitro. Hlm. 439-443.

Kulkarni SK, Dhir A. 2010. An Overview of Curcumin in Neurological Disoerders. Indian J Pharm Sci 72(2): 149-154.

Manjeshwar SB, Ramakrishna JP, Harshith PB, Princy LP, Rekha B.2011. Food Research International 44: 1823-1829. 
Muttaqin A.2009. Buku Ajar Asuhan Keperawatan Klien dengan Gangguan sistem Kardiovaskular dan Hematodologi. Jakarta: Salemba Medika. Hlm. 44-53.

Nurdiana. 2008. Efek 17-Estradiol Terhadap Densitas Reseptor Adrenergik-Id dan Kontraktilitas Otot Polos Pembuluh Darah Tikus. J Ked Braw 24(4): 141-148

Payne JR, Brodbelt DC, Luis Fuentes V. 2015.Cardiomyopathy prevalence in 780 apparently healthy cats in rehoming centres (the CatScan study) $J$ Vet Cardiol 17(Suppl 1): S244-257. doi: 10.1016/ j.jvc..03.008.

Poongodi T, Nazeema TH. 2016.In Vitro Cytooxicity, Phytochemistry and GC- MS Analysis of Averrhoa Carambola (Leaf) Against MCF-7 Breast Cancer Cell Line. Int J Cur Res 8(4): 29044-29048.

Rohaimi, Tan MSMZ, Ismail S, Mahmud R. 2012. Standardization and Phytochemical Studies Of Curcuma Xanthorrhiza Roxb. Int J Pharm Pharm Sci 3(4): 606-610

Roqaiya M, Wajeeha B, Sana F M, Amrin S. 2015. A Review On Traditional Uses and Phytochemical Properties Of Mimusops Elengi Linn. Int $J$ Herb Med 2(6): 20-23

Rukayadi Y, Yong D, Hwang JK. 2006. In Vitro Anticandidal activity of Xanthorrhizol isolated from Curcuma xanthorrhiza Roxb. Journal of Antimicrobial Chemotherapy (57): 1231-1234.

Septian BA, Widyaningsih TD. 2014.Peranan Senyawa Bioaktif Minuman Cincau Hitam (Mesona palustris $\mathrm{Bl}$.) terhadap Penurunan Tekanan Darah Tinggi: Kajian Pustaka. J P Agr 2(3): 198-202.

Soncini R, Santiago MB, Orlandi L, Moraes GO, Peloso AL, dos Santos MH, Alves-da-Silva G, Paffaro VA Jr, Bento AC, Giusti-Paiva
A. 2011. Hypotensive effect of aqueous extract of Averrhoa carambola L. (Oxiladaceae) in rats: An in-vivo and invitro approach. J Ethnopharmacol 27: 133(2): 353-357.

Srivita E. 2012. Isolasi dan Analisis Kimia Minyak Atsiri dari Temulawak (Curcuma Xanthoriza Roxb) dengan Gas Kromatografi-Spektrometer Massa (GcMs) dan Uji Aktivitas Anti Bakteri. Tesis. Medan. Universitas Sumatera Utara.

Theofilogiannako EK, Boudoula KD, Gawronski BE, Langaee TY, Kelpi TG, Pitsi AA, Johnson JA, Boudoula H. 2013. Betaadrenergic receptor polymorphisms: A basis for pharmacogenetics. WJCD 3:406411

Vasconcelos CML, Araujo MS, Silva BA, CondeGarcia EA. 2005. Negative inotropic and chronotropic effects on the guinea pig atrium of extracts obtained from Averrhoa carambola L. leaves. Braz J Med Biol Res 38(7): 1113-1122.

Vasconcelos CML, Araujo MS, Silva BA, CondeGarcia EA. 2005. Negative inotropic and chronotropic effects on the guinea pig atrium of extracts obtained from Averrhoa carambola L. leaves. Braz J Med Biol Res 38(7): 1113-1122.

Wijaya SM, Farida N, a Asnar E. 2012 Sweet star fruit reduces blood pressure in normotensive subjects. Folia Medica Indonesiana Vol. 48 No. 4: 198-202

World Health Organization, Global Health Estimates 2014 Summary Tables: Deaths by Cause, Age and Sex, by WHO Region, 2000-2012, http://www.who.int/ healthinfo/global burden disease/en/2014 [Internet] Accessed: Monday $23^{\text {rd }}$ March 2015, Available from. 